\title{
BIOLOGICAL VALUES OF CULTIVATED MUSHROOMS - A REVIEW
}

\author{
J. VETTER* \\ Department of Botany, University of Veterinary Sciences, H-1077 Budapest, Rottenbiller u. 50. Hungary
}

(Received: 3 July 2018; accepted: 11 October 2018)

\begin{abstract}
Cultivated mushrooms are not only valuable foods of our age (functional foods) but contain certain beneficial chemical components (high level of $\mathrm{K}$ and $\mathrm{P}$, very low content of $\mathrm{Na}$, considerable quantities of some microelements, high and valuable protein but low fat contents). Some cultivated mushrooms have anti-carcinogenic effects caused first of all by polysaccharides (Lentinan: Lentinula edodes) and by triterpenoids (ganoderic acids: Ganoderma lucidum or unsaturated fatty acids: linoleic, linolenic acids); antidiabetic effects, which can improve the sugar metabolism of patients (Coprinus comatus, Ganoderma lucidum, Agaricus bisporus); anti-microbial effects, caused partly by smaller triterpenoids or by higher molecules, i.e. by direct or indirect effects: via stimulation of the immune system. Certain mushrooms have antioxidant effects, provided mostly by higher radical scavenging activity of phenolic (flavonoid) components. The chemical composition and its biological effects form together the biological values of the cultivated mushrooms.

The following review would like to summarize the most important facts of this topic.

Keywords: cultivated mushrooms, chemical components, nutritional values, anti-carcinogenic, antidiabetic, antimicrobial, antioxidant effects
\end{abstract}

Mushrooms have been consumed since earliest historical times; Greeks believed that mushrooms provided strength for warriors, the Romans named them as the "Food of the Gods". In countries of the Orient, certain mushrooms were believed "elixir of life" etc. Mushrooms were used and valued as culinary delicacies and as medicines by the Greek, Egyptian, Roman, Chinese and Mexican civilizations.

Mushrooms were interpreted earlier as a specific (modified) group of plant kingdom; today they are fungi belonging to Regnum Fungorum; these species have macroscopic fruiting bodies (carpophores) and may be ranked to Ascomycota and mainly to Basidiomycota phylums.

\section{Cultivated mushrooms as functional foods}

The term "functional food" was used first in Japan in the 1980s. In 1996 a European Consensus on "Scientific Concepts of Functional Food" was developed, which was published in 1999 (RoBERFROID, 2002). The main aspects of this scientific definition are:

1. The functional food affects positively one or more functions of the body beyond adequate nutritional effects;

2. Its effect can be the improving of health and well-being (fitness) or reduction of risk of disease; it is not a capsule or tablet, but part of the normal food pattern.

* Phone: +36 1478 4238; e-mail: Vetter.Janos@univet.hu 


\section{Composition and nutritional values of cultivated mushrooms}

Use of fungi as foods is in vogue since ancient times, archaeological evidences documented it for the inhabitants of Chile almost 13000 years ago (GHORAI et al., 2009).

Exact historical data may document the beginning of the mushroom growing for France (in XVII-XVIII centuries). The modern mushroom growing or industry has shown a spectacular expansion in the last decades: over a 15-year period (1997 to 2012) consumption of mushrooms per capita increased drastically from about $1 \mathrm{~kg} /$ year to over $4 \mathrm{~kg} /$ year (RoYSE, 2014).

\subsection{Inorganic components}

Water is an essential component of all living things including the mushrooms. Interpretability of osmotic relations, nutrition, transpiration, growth, and development as main life processes is impossible without water. The water content of fruiting bodies is high (average is about $90 \%$ ), exception is for example the hard, dry fruiting body of Ganoderma lucidum. Contents of most important macro- and microelements are summarized in Table 1 based on data from scientific literature including earlier publications of our own.

Table 1. Mineral components in the most frequently cultivated mushrooms (in $\mathrm{mg} \mathrm{kg}^{-1} \mathrm{DM}, 1$ : pileus /cap/; 2: stipe; 3: whole fruiting bodies)

\begin{tabular}{lccccccccc}
\hline Mushroom species & & $\mathrm{K}$ & $\mathrm{P}$ & $\mathrm{Mg}$ & $\mathrm{Ca}$ & $\mathrm{Na}$ & $\mathrm{Cu}$ & $\mathrm{Zn}$ & $\mathrm{Mn}$ \\
\hline Agaricus bisporus & 1 & 39000 & 12150 & 1410 & 1388 & 699 & 39.5 & 64.7 & 8.31 \\
& 2 & 37182 & 9120 & 1088 & 1818 & 942 & 29.2 & 55.7 & 6.47 \\
Agaricus subrufescens & 1 & 30700 & 11770 & 1160 & 958 & 140 & 151 & 254 & 8.8 \\
& 2 & 28400 & 6790 & 990 & 1520 & 188 & 73 & 144 & 6.1 \\
Pleurotus ostreatus & 1 & 30700 & 6980 & 1369 & 820 & 269 & 18.7 & 76.6 & 9.6 \\
& 2 & 21386 & 2950 & 933 & 853 & 265 & 20.2 & 36.5 & 6.23 \\
Pleurotus eryngii & 1 & 22303 & 9961 & 1530 & 882 & 792 & 11.5 & 68.2 & 9.9 \\
& 2 & 16659 & 6562 & 1264 & 1008 & 721 & 8.9 & 40.2 & 5.3 \\
Lentinula edodes & 1 & 23200 & 7412 & 1341 & 1148 & 439 & 13.2 & 82.2 & 21.4 \\
& 2 & 11840 & 3772 & 1420 & 1330 & 454 & 8.1 & 49.9 & 16.9 \\
Agrocybe cylindracea & 1 & 24500 & 13800 & 1570 & 60 & 60 & 30 & 80 & 10 \\
Flammulina velutipes & 2 & 37500 & 13200 & 1640 & 120 & 90 & 30 & 80 & 10 \\
Volvariella volvacea & 3 & 28000 & $\mathrm{n} . \mathrm{d}$. & 1108 & 324 & 188 & 2.7 & 27 & 7.0 \\
Auricularia auricula & 3 & 13240 & 16990 & 570 & 4460 & 2580 & 160 & 680 & 52 \\
Coprinus cinereus & 3 & $4-5000$ & 1480 & 500 & $1800-$ & 104 & 9 & 38 & $\mathrm{n} . \mathrm{d}$.
\end{tabular}

(Based on publications of GYÖRFI and co-workers, 2010; VETTER, 2010; KALAC, 2012; KRÜZSELYI and co-workers, 2016); n. d.: no data 
Potassium is the main and first mineral component in all mushrooms including wildgrowing species, too. Level of $\mathrm{K}$ in caps is significantly higher than in stipes, but the rate of $\mathrm{K}_{\text {cap }}$ to $\mathrm{K}_{\text {stipe }}$ is different: in Agaricus bisporus it is about only 1.05, whereas for Lentinula edodes this rate is 1.88 (22.3 $\mathrm{g} \mathrm{kg}^{-1} \mathrm{DM} /=$ dry matter/ for cap and $11.8 \mathrm{~g} \mathrm{~kg}^{-1} \mathrm{DM}$ for stipe). The highest potassium levels are found in Agaricus spp., followed by Pleurotus spp. Proper $\mathrm{K}$-care is an essential element of our up-to-date, healthy nutrition, so the K-content of a food is also a factor of medical significance.

Biological importance of phosphorus containing molecules is beyond doubt. P-content of cultivated mushrooms (Table 1) is remarkable, but the variability of these data is significantly high; nutrition type of mushrooms can influence the actual P content: wood decaying mushrooms (Pleurotus species or Lentinula edodes) have lower P-levels.

Magnesium and calcium are classified to the macroelements, their contents vary between 500-1500 mg kg-1 DM; quantities of these two elements are mostly around identical or Mglevel is higher than Ca-quantity (exceptions: Volvariella volvacea and Coprinus sp.).

Sodium contents vary between 100 and some hundred $\mathrm{mg} \mathrm{kg}^{-1} \mathrm{DM}$ (Table 1). Let's take a short calculation: $1 \mathrm{~kg}$ dry mushroom contains for example $300 \mathrm{mg} \mathrm{Na}$; ingestion of $100 \mathrm{~g}$ fresh mushroom means the uptake of $3 \mathrm{mg} \mathrm{Na}$ only, which is a negligible quantity (compared to other food types). Consumption of mushroom means the uptake of significant potassium quantity (ingestion of $100 \mathrm{~g}$ fresh mushroom means about $300 \mathrm{mg} \mathrm{K}$, the rate of $\mathrm{K}$ to $\mathrm{Na}$ is: 100:1). This rate (which differs absolutely from other food types) seems to be a very essential biological value for consumers.

Data presented in Table 1 have contents of three important microelements, namely $\mathrm{Cu}$, $\mathrm{Zn}$, and $\mathrm{Mn}$; the general situation for their contents: $\mathrm{Zn}>\mathrm{Cu}>\mathrm{Mn}$.

The process of bioaccumulation is described for mushrooms, meaning a specific, extreme uptake and/or storage of certain mineral elements (VetTER, 1994, 1996; KalaC \& Svoboda, 2000; Kalac, 2016). Cu bioaccumulation is described for example for Macrolepiota species, extreme vanadium (V) accumulation characterizes the species Amanita muscaria, or arsenic (As) accumulation can be measured in fruiting bodies of Laccaria amethysthea or Sarcosphaera coronaria. Such processes are caused by synthesis and function of specific, "binding" organic molecules, which can absorb high (or extreme) quantities of the given element (As, $\mathrm{Cu}, \mathrm{V}$, and others). Accumulation of Se is characteristic mainly of wild growing Boletus spp. (25-40 $\mathrm{mg} \mathrm{kg}^{-1} \mathrm{DM}$ ) or of species Albatrellus pres-caprae (VETTER \& LeLLEY, 2004), while Se content of other species is usually not more than $0.1-0.2 \mathrm{mg} \mathrm{kg}^{-1} \mathrm{DM}$. Fruiting bodies of Pleurotus ostreatus, P. eryngii, or Lentinula edodes contain relatively low Se quantities, but different varieties of Agaricus bisporus have mostly $3-5 \mathrm{mg} \mathrm{kg}^{-1} \mathrm{DM}$ contents (VETTER \& LELLEy, 2004).

\subsection{Organic constituents}

Main organic constituents of cultivated mushrooms are given in Table 2 (in \% of DM) based on different literature sources.

Published data of crude protein contents (N-content $\times 4.38)$ show great variability, the highest values characterize the Agaricus species: up to $36 \%$ for A. bisporus, up to $39 \%$ for A. subrufescens, and lower contents can be measured in wood decaying species (Lentinula edodes: 11-20\%; Pleurotus ostreatus: 12-21\%; Flammulina velutipes: $15-26 \%$ ), see SALESCAmpos and co-workers, (2011) and KALAC, (2016). 
Table 2. Nutritional values of the most frequently cultivated mushroom species

\begin{tabular}{lcccc}
\hline Mushroom species & $\begin{array}{c}\text { Crude protein } \\
(\% \mathrm{DM})\end{array}$ & $\begin{array}{c}\text { Crude fat } \\
(\% \mathrm{DM})\end{array}$ & $\begin{array}{c}\text { Carbohydrate } \\
(\% \mathrm{DM})\end{array}$ & $\begin{array}{c}\text { Energy } \\
(\mathrm{kcal} / 100 \mathrm{~g} \mathrm{DM})\end{array}$ \\
\hline Agaricus bisporus & $14.0-36.3$ & $0.8-2.5$ & $50.9-74.0$ & $303-325$ \\
Agaricus subrufescens & $26.2-39.3$ & $0.9-4.0$ & $39-64.0$ & $340-360$ \\
Pleurotus ostreatus & $7.0-23.8$ & $0.5-5.4$ & $51.9-85$ & 416 \\
Pleurotus eryngii & $11.0-22.0$ & $1.45-1.57$ & $70.5-81.4$ & 421 \\
Lentinula edodes & $4.4-20.5$ & $1.7-6.3$ & $67.9-87.0$ & 386 \\
Agrocybe cylindracea & $16.5-22.2$ & $3.5-3.6$ & $\mathrm{n} . \mathrm{d}$. & $130-179$ \\
Flammulina velutipes & $3.9-26.6$ & $2.9-9.23$ & $56.6-85.9$ & 467 \\
Volvariella volvacea & 36.5 & 2.2 & 52.3 & $\mathrm{n} . \mathrm{d}$. \\
Auricularia auricula & $5.7-15.5$ & $0.4-4.5$ & $77-91$ & $97-140$ \\
Coprinus comatus & 10.9 & 1.98 & 76.5 & 368 \\
Ganoderma lucidum sensu lato & 13.3 & 3.0 & 82.3 & $\mathrm{n} . \mathrm{d}$. \\
\hline
\end{tabular}

(Ulzijargal \& Mau, 2011; Hung \& Nhi, 2012; Kalac 2012; Pardo-Gimenez and co-workers, 2013); n. d.: no data

Formerly we compared (VetTER \& Rimóczi, 1993) the protein levels in caps and stipe of P. ostreatus in different phases of maturation (according to the average diameter of caps: $<5$ $\mathrm{cm} ; 5-8 \mathrm{~cm} ; 8-10 \mathrm{~cm} ;>10 \mathrm{~cm}$ ). The protein content of caps was highest in the second phase (25.4\% DM), before and after this phase the crude protein levels were lower.

Qualification of mushroom proteins is possible for example by contents and rates of essential amino acids, or by occurrence and rate of sulphur containing amino acids. Distributions of essential amino acids range between 32.9 and $48.9 \%$ of total amino acid content, $32.9 \%$ for A. bisporus varieties, $41-44 \%$ for Pleurotus species, and $41-44 \%$ for Lentinula edodes (VETTER, 2010). The relative occurrence of sulphur containing amino acids fluctuates between 1.4 and $4.5 \%$ (lower data characterize the Agaricus and Pleurotus species).

Other aspect of protein qualification is the evaluation based on solubility according to the "classical" fractionation by Osborne (albumins, globulins, prolamins, and glutelins). The solubility (or its absence) has a great biological role in uptake, digestion, and absorption of proteins, yet very limited data are available for mushrooms (BAUER-PETRONSKA, 2001). Our recent investigations (KRÜZSELYI et al., 2016) provide new facts. Percentage distribution of albumins (or albumins + globulins) is very high and beneficial (about $80 \%$ of total true proteins for $P$. eryngii and about $60 \%$ for $P$. ostreatus).

Biological quality of fungal proteins is affected by different species and strains, growing methods, composition of substrates, age and development of fruit body (VETTER \& RimóczI, 1993; Del Toro et al., 2006, Cheung, 2008).

Crude (total) fat content of mushrooms is in general low $(0.5-3 \%$ for DM). The actual fat content of $100 \mathrm{~g}$ fresh fruit body is about practically only one tenth $(0.05-0.3 \%)$ of these values. A logical consequence of this low fat content is the low energy level of the mushrooms (see later). The rate of polyunsaturated fatty acids in mushrooms including cultivated ones is high, about $75 \%$ of total fatty acids. Most frequent components are linoleic (68-84\%), palmitic (19.2\%), and oleic acids (8.3\%) (CHEUNG, 2008). Cultivated mushrooms contain high amounts of sterols (MatTILA et al., 2001), mainly ergosterol. Ergosterol contents of cultivated mushrooms were $780 \mathrm{mg} / 100 \mathrm{~g}$ DM for A. bisporus, 605 for L. edodes, 440 for $P$. ostreatus and for P. abalone, and only 68 for Flammulina velutipes (JASINGHE et al., 2005). 
Carbohydrates

Total carbohydrate content (calculated for DM) of the mushrooms is high, but it varies. This fraction contains monosaccharides, mainly as free sugars (glucose, fructose, mannose, arabinose, etc.) or sugar alcohols (mainly mannitol). Oligosaccharides (as trehalose) can be important components, while polysaccharides are the main cell wall components. The glucans (mainly $\beta$-glucans) have not only specific chemical structures $(\beta(1 \rightarrow 3) ; \beta(1 \rightarrow 4), \beta(1 \rightarrow 6)$ glycosidic linkages) but also their biological importance is extremely high (see later in section of medicinal effects of mushrooms).

Chitin molecules are composed of $\mathrm{N}$-acetyl-glucose-amine units, and they are responsible for rigidity and shape of fungal cell wall. Chitin levels in fruit bodies of cultivated mushroom range between 2 and 8.5 percent of DM (VETTER, 2007).

Biological effects of mushroom polysaccharides (glucans and mainly chitin) on digestive enzymes of consumers are in close connection with the problem of dietary fibres. The chitin and the matrix components ( $\alpha$ - and $\beta$-D-glucans and mannans) are nonstarch polysaccharides, which molecules can be classified as total dietary fibre fraction (Cheung, 2008; 2013). These molecules are practically resistant to digestion and absorption in human small intestine and have beneficial effects such as laxation or attenuation of glucose and/or cholesterol in blood. The dietary fibre has two main fractions: the soluble and the insoluble ones. The total dietary fibre values of $A$. bisporus and $P$. ostreatus species are significantly different: $23 \% \mathrm{DM}$ and 48-51\% DM, respectively (DikEMAn et al., 2005; SyNYTSYA et al., 2008).

Energy content of cultivated mushrooms is generally low; they belong to diet of low energy. Values of Table 2 are calculated for $100 \mathrm{~g}$ DM, which means practically $1 \mathrm{~kg}$ of fresh mass. Ingestion of about $100 \mathrm{~g}$ fresh mushroom from A. bisporus gives approximately $30-$ $32.5 \mathrm{kcal}$ energy, for Pleurotus species these values are slightly higher (41-42 kcal), but the use of Agrocybe cylindracea and even more of Auricularia auricula means 13-17 and 9-14 kcal energy (Cheung, 2008). The demonstrated low energy content is one of the nutritional and health benefits of mushrooms.

Flavour and taste components

Majority of these substances can stimulate production of digestive enzymes; uptake and utilisation of nutrients can be better. Number of fragrance substances having identified chemical structure is more than 150; they have mainly alcoholic character. One of the most characteristic flavour components is the 1-octen-3-ol, the "mushroom alcohol". Fruit bodies of $L$. edodes belong to mushrooms of very characteristic fragrance, it is determined by a specific, S-containing molecule: the lenthionine: 1,2,3,5,6-pentathiepane (VETTER, 2010).

The pleasant almond flavour of Agaricus subrufescens is formed by interactions of benzaldehyde, benzoic acid, benzyl alcohol, methyl benzoate, and 4-hydroxi-benzaldehyde (STIJVE et al., 2002).

Vitamins

In general, vitamin B type contents (mainly $\mathrm{B}_{3}$ ) are higher, between 300 and 650 $\mathrm{mg} \mathrm{kg}{ }^{-1} \mathrm{DM}$; in addition, the levels of folates range between 3000 and $6400 \mu \mathrm{g} \mathrm{kg}^{-1} \mathrm{DM}$ (Lelley \& VetTer, 2005). Biological and medicinal importance of vitamin $\mathrm{D}_{3}$ nowadays is very high, but our cultivated mushrooms have very low (in some cases not detectable) levels. It was shown that UV-B irradiation of cultivated mushrooms (mainly of A. bisporus) can produce considerable concentrations of vitamin $\mathrm{D}_{2}$ : ergosterol molecules are transformed in $\mathrm{D}_{2}$. Most studies have shown significant amount of vitamin $\mathrm{D}$ content in UV irradiated mushrooms for Agaricus, Pleurotus species and Lentinula edodes, too (see review of TAOFIQ and co-workers, 2017). 
Fruiting bodies of cultivated mushrooms contain different quantities of vitamin C 170 $200 \mathrm{mg} \mathrm{kg}^{-1}$ DM (BERNAs et al., 2006). Calculating for daily ingestion of fresh matter $(100 \mathrm{~g}$ fresh mushroom/capita): the possible daily uptake of vitamin $\mathrm{C}$ by mushroom is about only 2 mg.

\section{Medicinal values of cultivated mushrooms}

\subsection{Anticarcinogenic substances and effects}

Cell wall of all basidiomycetous mushrooms has certain polysaccharides, as $\beta$-glucans and chitins. Individual chains of these are linked; covalent bonds are formed between two polysaccharides. Quantity of the $\beta$-glucane fraction varies between 22 and $52 \mathrm{mg} / 100 \mathrm{~g}$ DM (Manzi \& Pizzoferrato, 2000; see Table 3). The glucanes have water-soluble and waterinsoluble sub-fractions: lower part (18-46\%) belongs to water soluble, the higher one (53$83 \%)$ to insoluble fraction. Lentinan ( $($-glucan from $L$. edodes) is a $(1 \rightarrow 3)-\beta$-D-glucan having two $(1 \rightarrow 6)$ glucopyranoside branches for every five $(1 \rightarrow 3)$ - $\beta$-glucopyranoside linear linkage.

Table 3. ß-Glucan contents and percentages of water-soluble and water-insoluble fractions in Lentinula edodes and in different Pleurotus species

\begin{tabular}{lccc}
\hline Mushroom & $\begin{array}{c}\text { B-Glucan content } \\
(\mathrm{g} / 100 \mathrm{~g} \mathrm{DM})\end{array}$ & $\begin{array}{c}\text { Water-soluble } \text { B-glucan } \\
(\%)\end{array}$ & $\begin{array}{c}\text { Water-insoluble } \beta \text {-glucan } \\
(\%)\end{array}$ \\
\hline Lentinula edodes & 0.22 & 46.1 & 53.9 \\
Pleurotus ostreatus & 0.38 & 37.8 & 62.2 \\
P. eryngii & 0.38 & 16.8 & 83.2 \\
P. pulmonarius & 0.53 & 18.7 & 81.3 \\
\hline
\end{tabular}

Based on Manzi \& Pizzoferrato (2000)

Anti-cancer effect of $L$. edodes (of $ß$-glucan lentinan) was firstly reported by CHIHARA and co-workers (1970). Sarcoma 180 cancer cells were transplanted in CD-1/ICD mice and lentinan has been shown to inhibit the growth of cancer cells. The preoperative treatment by lentinan can cause significant reduction of lung metastasis colony numbers in humans (see review of ZHANG and co-workers, 2011). The combination of pre- and post-operative therapy with lentinan may be effective to prevent cancer recurrence and metastasis after surgical treatments. The main factor of its anti-cancer action is the immuno-stimulating activity against cancer (without or in combination with chemotherapy). Lentinan is probable a host defence potentiator, which may restore or increase the sensitivity of host cells to different molecules as to interleukins, hormones, etc. Lentinan can promote host resistance of the cells against different cancer forms, as well as different types of natural killer cells. Stimulation seems to be probable for T-cell-, B-cell-, and macrophage-dependent immune system responses, too (WASSER \& WeISS, 1999). Antitumor effect of lentinan was significantly stronger than of other polysaccharides of fungal or plant origin. Lentinan was administered to Chinese patients orally or intravenously (ZHANG et al., 2011).

A treatment by Pleurotus ostreatus powder could be a possible therapy in colon carcinogenesis (suppression of enzyme activities was demonstrated in mice). Pleuran is a 
ß-glucan type, having significant anticarcinogenic and immunostimulant effects. P. eryngii can produce different $\beta, 1 \rightarrow 3$ glucans, too, with immune-modulating and antitumor activities (StAJic et al., 2009).

Compounds of almond mushroom (Agaricus subrufescens) with anti-cancer effect were first extracted by KAWAGISHI and co-workers (1989). The anti-cancer activity of polysaccharides (mainly of ß-glucans) was verified by numerous researchers (LISIECKA et al., 2013), and it was shown that the productions of interferon and interleukins are stimulated. Agaricus bisporus is a potential breast cancer chemopreventive agent by suppression of aromatase activity and oestrogen biosynthesis (CHEN et al., 2006). Its main active compounds are unsaturated fatty acids as linoleic acid, linolenic acid, and conjugated linoleic acid, which can bind to the active site of aromatase enzyme (as non-competitive inhibitors).

Ganoderma lucidum sensu lato (reishi) fruiting bodies possess anticarcinogenic substances as triterpenes and some glucan molecules (KAO et al., 2013). Such triterpenes are: ganoderic acid T, D and ganoderiol F. G. lucidum extract can end the cell cycle at the G1 phase (JEDINAK et al., 2011), by a down regulation of cyclin D1 molecules (latter are essential regulators for $\mathrm{G} 1 / \mathrm{S}$ transition in the cell cycle). Induction of apoptosis was detected by triterpenes of reishi. Other essential effect of reishi triterpenes is the reduction of cancer metastasis (by regulation of some key proteins). Ganoderic acid for example can inhibit the activity of matrix metalloproteinase protein family responsible for promotion of metastasis.

Mode of the anti-cancer action of $\beta$-D-glucans isolated from G. lucidum seems to have three main mechanisms:

a) Improved immune responses (the stimulation of macrophages, natural killer (NK) cells, and cytotoxic T lymphocytes); b) Higher anti-oxidative activity (which can reduce the oxidative damage); c) Inhibition of angiogenesis.

Limited clinical studies (case reports, randomized controlled trials) suggest reishi as an alternative adjunct therapy for improvement of immune system of cancer patients (CHENG \& SLIVA, 2015).

\subsection{Antidiabetic substances and effects}

Development of diabetes is controlled by multiple inherited and environmental factors (DE Silva et al., 2012). Type 1 diabetes occurs due to inherited factors, but type 2 diabetes is due mainly to environmental factors (including nutritional ones). A significant anti-glycaemic effect was produced by white button mushroom (A. bisporus) fruiting bodies ingested by diabetic rats (JEONG et al., 2010). This is probably a multicomponent effect, originating from different constituents including dietary fibres, some anti-oxidants, proteins, and polysaccharides. The $\beta$-glucan fraction can reduce blood glucose level, and can improve the pancreatic $\beta$-cells: by inhibition of $\alpha$-glucosidase activity and by stimulation of insulin production (HigaKi et al., 2005).

Pleurotus ostreatus extracts (especially in higher concentrations) reduced blood glucose level in hyperglycaemic rats (GHALY et al., 2011). A significant correlation was found between mushroom supplementation and reduction of high blood sugar content for 120 diabetic patients of type 2 (Agrawal et al., 2010).

An exopolymer produced by submerged mycelia culture of shiitake decreased plasma glucose level by $21.5 \%$ and increased insulin level by $22 \%$ in diabetic rats (YANG et al., 2002). The "effective" molecule is a glycoprotein (molecular mass 52 000, protein content $16.5 \%$, carbohydrate content $83.5 \%$ ). 
Fruiting bodies of Coprinus comatus (ink cap mushroom) have one anti-diabetic molecule, the comatin (4,5-dihydroxi-2-methoxy-benzaldehyde). It is an inhibitor for nonenzymatic glycosylation. Blood glucose content of rats (treated with comatin at $80 \mathrm{mg} \mathrm{kg}^{-1}$ bw.) was reduced from $5.14 \mathrm{mM}$ to $4.28 \mathrm{mM}$ in $3 \mathrm{~h}$ (Ding et al., 2010). Glucose lowering activity of $G$. lucidum polysaccharides is related to facilitation of $\mathrm{Ca}^{2+}$ influx into ß-cells of pancreas and thus to insulin release. A reversion of viability of pancreatic islets was found in animal model experiments (ZHANG et al., 2003). Ingestion of Ganoderma polysaccharides is beneficial for therapy of diabetes type 2; they can decrease the serum glucose level via hepatic phosphoenolpyruvate carboxykinase. This suppression can cause a decrease (lowering) in gluconeogenesis (SETo et al., 2009). In a randomized, placebo-controlled clinical study, the ganopoly (an extracted polysaccharide fraction of mushroom) was given to 71 patients of diabetes type 2 and a blood glucose lowering was demonstrated (GAO et al., 2004).

Antidiabetic effect of Auricularia auricula-judae (=Hirneola auricula-judae) was demonstrated in diabetic mice; ingestion of mushroom had a lowering effect in plasma glucose, in total cholesterol, and in triglyceride levels (KIM et al., 2007). The maitake mushroom (Grifola frondosa) can lower blood sugar level by its $\alpha$-glucosidase inhibitors (HoNG et al., 2007).

\subsection{Antimicrobial substances and effects}

Mushrooms need different antimicrobial compounds to survive and reproduce in natural environment. An alcoholic extract of white button mushroom was tested in vitro, and it had strongly inhibited the growth of some Gram-positive bacteria (Bacillus subtilis, Staphylococcus aureus, and Pseudomonas aeruginosa (JAGADISH et al., 2009). Extracts of fresh or dehydrated fruiting bodies of mycelium of $P$. ostreatus inhibited the growth of Bacillus subtilis and Escherichia coli (KHAN \& TANIA, 2012).

Certain triterpenes of Ganoderma lucidum sensu lato, as ganoderol F, ganodermanontriol, and ganoderic acid B, have direct antiviral effects against HIV-1. Lentinan has shown antiviral activity in animal experiments (against vesicular stomatitis virus, encephalitis virus, Abelson virus, and adenovirus type 12). The mode of action of its antiviral effects is indirect; the immune system is stimulated.

Some Pleurotus species have shown certain antiviral effects. A laccase enzyme was isolated and purified from $P$. ostreatus fruiting bodies inhibiting the entry and replication of hepatitis $\mathrm{C}$ virus. Other laccase variant from $P$. cornucopiae can decrease the activity of HIV-1 reverse transcriptase (see review of KHAN and TANIA, 2012).

\subsection{Antioxidant substances and effects}

Antioxidant capacity of mushrooms can be characterized approximately by contents of phenolics or there are different methods for estimation of the actual "capacity" of this system (measurement of reducing power, of inhibition of lipid peroxidation, evaluation of scavenging activity for free radicals, etc.).

Total phenolic content of certain cultivated mushroom fruiting bodies are demonstrated in Table 4 (WANG \& XU, 2014). Phenolic compounds may provide antioxidative character via different ways, such as decomposing primary products of oxidation, intercepting singlet oxygen, etc. The antioxidant property of Coprinus comatus fruiting bodies is provided by their naturally occurring components as ascorbic acid $\left(0.04-2.95 \mathrm{mg} \mathrm{g}^{-1}\right)$, total tocopherol content (0-4.94 $\left.\mathrm{mg} \mathrm{g}^{-1}\right)$, and total phenolics (2.3-7.3 $\left.\mathrm{mg} \mathrm{g}^{-1}\right)$ (Tsar et al., 2009). Study of SuN 
and co-workers (2004) revealed that the peptide fraction is the major antioxidant of $G$. lucidum sensu lato.

Table 4. Total phenolic contents and free radical scavenging activity of some cultivated mushrooms

\begin{tabular}{lcccc}
\hline Mushroom & $\begin{array}{c}\text { Total phenolics } \\
\text { from water extract } \\
(1)\end{array}$ & $\begin{array}{c}\text { Total phenolics } \\
\text { from hot water } \\
\text { extract }(2) \\
(\mathrm{mg} \mathrm{GAE} / \mathrm{g} \mathrm{DM})\end{array}$ & $\begin{array}{c}\text { DPPH free radical } \\
\text { scavenging activity } \\
(1)\end{array}$ & $\begin{array}{c}\text { DPPH free radical } \\
\text { scavenging activity } \\
(2)\end{array}$ \\
\hline Agaricus subrufescens & 2.82 & 1.01 & 4.94 & 3.76 \\
Pleurotus eryngii & 3.65 & 1.52 & 3.72 & 4.45 \\
Lentinula edodes & 4.26 & 1.82 & 1.40 & 2.93 \\
Auricularia auricula & 0.82 & 0.35 & 2.42 & 2.18 \\
Agrocybe cylindracea & 5.71 & 2.99 & 3.32 & 4.64 \\
Grifola frondosa & 3.78 & 2.34 & 1.75 & 2.47 \\
Pholiota nameko & 7.31 & 2.15 & 2.13 & 3.99 \\
\hline
\end{tabular}

Based on data of WANG \& Xu (2014)

GAE: gallic acid equivalent; TE: Trolox equivalent; DPPH: $\alpha, \alpha$-diphenyl- $\beta$-picrylhydrazyl

\section{Conclusions}

Chemical composition (occurrence, quantity, and rates of certain constituents) determines the biological value of our cultivated mushrooms. Main biological values of mushrooms are specified as follows:

- Mineral composition of fruiting bodies differs completely from other living groups. Four mineral elements give $97-98 \%$ of total quantity; K and P have the highest amounts, supplemented with a very low sodium level. Occurrence of selenium (mainly in Agaricus species and varieties) can be beneficial for its biological effects.

- Concentration of the favourable protein molecules fluctuates between 25 and $35 \%$ for DM. Metabolism and utilisation of these proteins are basically determined by the beneficial rate of essential amino acids and by occurrence of proteins from albuminglobulin groups ( $81.6 \%$ for P. eryngii and $66 \%$ for P. ostreatus). Crude fat content is low $(0.5-5.4 \% \mathrm{DM})$, having a role in low energy values of mushrooms. Crude carbohydrate content ranges between 50 and $85 \%$ of DM. Compounds of dietary fibre group (insoluble polysaccharides including some glucans and chitin) give a substantial rate of total carbohydrates. Their biological effect is beneficial for digestion; anti-cancer effects of certain glucans (mainly of $\beta$-glucans) nowadays become more and more important.

- Substances responsible for taste and fragrance of mushrooms can stimulate digestion and absorption of nutrients.

- Dynamic increase of cultivation of certain mushrooms (as A. subrufescens, Pleurotus eryngii, Grifola frondosa, or Ganoderma lucidum sensu lato) is interpretable by existence of medicinal compounds. The anti-cancer (anticarcinogenic) effects of these mushrooms have outstanding importance. These effects are mainly connected to B-glucans (for example: lentinan from L. edodes) and to certain triterpene derivatives (ganoderic acid T, D) or to some unsaturated fatty acids (linoleic acid, linolenic acid). These ingredients mostly activate different components of the immune system. 
Medicinal use of these substances is possible in therapy or in prevention, alone or in combination.

- Certain cultivated mushrooms (A. bisporus, P. ostreatus, Coprinus comatus, and Ganoderma lucidum sensu lato) have antidiabetic effects, which can improve the glucose metabolism mainly for patients of diabetes type 2. Extracts of many cultivated mushrooms have antimicrobial effects against Gram-negative and Gram-positive bacteria and certain viruses (HIV-1, hepatitis C, vesicular stomatitis virus, encephalitis virus).

- The published scientific data justify occurrence of different substances with antioxidative character (phenolics, polysaccharides, etc.). Synergistic effect of these molecules may stimulate the free radical scavenging activity of these mushrooms.

According to an old Chinese proverb: "Medicine and food have a common origin". Cultivated mushrooms are excellent examples of this duality.

\section{References}

Agrawal, R.P., Chopra, G., Lavekar, G.S., Padhi, M.M., Srikanth, N., Ota, S. \& Jain, S. (2010): Effect of oyster mushroom on glycemia, lipid profile and quality of life in type 2 diabetic patients. Aust. J. Med. Herbalism, $22,50-54$

Bauer-Petrowska, B. (2001): Protein fractions in edible Macedonian mushrooms. Eur. Food Res. Technol., 212, $469-472$.

Bernas, E., Jaworska, G. \& Lisiewska, Z. (2006): Edible mushrooms as a source of valuable nutritive constituents. Acta Sci. Pol. Technol. Aliment., 5, 5-20.

Chen, S., Оh, S., Phung, S., Hur, G., Ye, J.J., ... \& W Williams, D. (2006): Anti-aromatase activity of phytochemicals in white button mushrooms (Agaricus bisporus). Cancer Res., 66, 12026-12034.

Cheng, S.J. \& SLiva, D. (2015): Ganoderma lucidum for cancer treatment: We are close but still not there. Integr. Cancer Ther., 14, 249-257.

CHeung, P.C.K. (2008): Nutritional value and health benefits of mushrooms. -in: CHEung, P.C.K. (Ed.) Mushrooms as functional foods. John Wiley and Sons Inc., Hoboken, New Jersey, USA, pp. 71-110.

CHeung, P.C.K. (2013): Mini-review on edible mushrooms as source of dietary fiber: Preparation and health benefits. Food Science and Human Wellness, 2, 162-166.

Chinara, G., Hamuro, J., Maeda, Y.Y., Arai, Y. \& Funuoka, F. (1970): Fractionation and purification of the polysaccharides with marked antitumor activity, especially lentinan from Lentinus edodes (Berk.) Sing. (an edible mushroom). Cancer Res., 30, 2776-2781.

De Silva, D.D., Rapior, S., Hyde, K.D. \& Bahkali, A.H. (2012): Medicinal mushrooms in prevention and control of diabetes mellitus. Fungal Divers., 56, 1-29.

Del Toro, G.V., Vega, R.C., Garin-Aquilar, M.E. \& Lara, H.L. (2006): Biological quality of proteins from three strains of Pleurotus spp. Food Chem., 94, 494-497.

Dikeman, C.L., Bauer, L.L., Flickinger, E.A. \& Fahey, G.C. JR. (2005): Effects of stage and maturity and cooking on the chemical composition of select mushroom varieties. J. Agr. Food Chem., 53, 1130-1138.

Ding, Z.Y., Lu, Y.J., Lu, Z.X., Iv, F.X., Wang, Y.H., Bei, X.M., Wang, F. \& Zhang, K.C. (2010): Hypoglycaemic effect of comatin, an antidiabetic substance separated from Coprinus comatus broth, on alloxan induceddiabetic rats. Food Chem., 121, 39-43.

GaO, Y., LAN, J., DAI, X., Ye, J. \& Zhou, S. (2004): A phase I/II study of lingzhi mushroom Ganoderma lucidum (W. Curt.:Fr.) Lloyd (Aphyllophoromycetidae) extract in patients with type II diabetes mellitus. Int. J. Med. Mushrooms, 6, 33-39.

Ghaly, I.S., Ahmed, E.S., Booles, H.F., FArag, I.M. \& NAdA, S.A. (2011): Evaluation of antihyperglycemic action of oyster mushroom (Pleurotus ostreatus) and its effect on DNA damage, chromosome aberrations and sperm abnormalities in streptozotocin-induced diabetic rats. Global Veterinaria, 7, 532-544.

Ghorai, S., Banik, S.P., Verma, D., Chowdury, S., Mukherjee, S. \& Khowala, S. (2009): Fungal biotechnology in food and feed processing. Food Res. Int., 42, 577-587. 
GYÖRfi , J., GeÖSEL, A. \& VetTeR, J. (2010): Mineral composition of different strains of edible medicinal mushroom Agaricus subrufescens Peck. J. Med. Food, 13, 1510-1514.

Higaki, M., Eguchi, F., Zhang, J., Kikukawa, T., Abe, C., Kato, K., Hasegawa, K. \& Watanabe, Y. (2005): Improvement of pancreatic beta-cells by hot water extract from cultured Agaricus blazei (CJ-01) fruiting bodies in GK rats. J. Tradit. Med., 17, 205-214.

Hong, L., Xun, M. \& Wutong, W. (2007): Anti-diabetic effect of an alfa-glucan from fruit body of maitake (Grifola frondosa) on KK-Ay mice. J. Pharm. Pharmacol., 59, 575-582.

Hung, P.V. \& NнI, N.Y. (2012): Nutritional composition and antioxidant capacity of several edible mushrooms grown in the Southern Vietnam. Int. Food Res. J., 19, 611-615.

Jagadish, L.K., Krishnan, V.V., Shenbhagaraman, R. \& Kaviyarasan, V. (2009): Comparative study on the antioxidant, anticancer and antimicrobial property of Agaricus bisporus (J.E. Lange) Imbach before and after boiling. Afr. J. Biotechnol., 8, 654-661.

Jasinghe, V.J., Perera, C.O. \& BARLow, P.J. (2005): Bioavailability of vitamin $\mathrm{D}_{2}$ from irradiated mushrooms: An in vivo study. Brit. J. Nutr., 93, 951-955.

Jedinak, A., Thyagarajan-Sahu, A., Jiang, J. \& Sliva, D. (2011): Ganodermanotriol, a lanostanoid triterpene from Ganoderma lucidum, suppresses growth and colon cancer cells through ss-catenin signalling. Int. J. Oncol., 38, 761-767.

Jeong, S.C., Jeong, Y.T., Yang, B.K., Islam, R., Koyyalamudi, S.R., Pang, G., Cho, K.Y. \& Song, C.H. (2010): White button mushroom (Agaricus bisporus) lowers blood glucose and cholesterol levels in diabetic and hypercholesterolemic rats. Nutr. Res., 30, 49-56.

KALAC, P. (2012): A review of chemical composition and nutritional value of wild-growing and cultivated mushrooms. J. Sci. Food Agr., 93, 209-218.

KalaC, P. (2016): Edible mushrooms. Chemical composition and nutritional value. Elsevier, Amsterdam, Tokyo. p. 207.

Kalac, P. \& Svoboda, L. (2000): A review of trace element concentrations in edible mushrooms. Food Chem., 69, 273-281.

Kao, C.H.J., Jesuthasan, A.C., Bishop, K.S., Glucina, M.P. \& Ferguson, L.R. (2013): Anti-cancer activities of Ganoderma lucidum: Active ingredients and pathways. Functional Foods in Health and Disease (FFHD), 3, $48-65$.

Kawagishi, H., Inagaki, R., Kanao, T., Mizuno, T., Shimura, K., Ito, H., Hagiwara, T. \& Nakamura, T. (1989): Fractionation and antitumor activity of the water-insoluble residue of Agaricus blazei fruiting bodies. Carbohyd. Res., 186, 267-273.

KHAN, A. \& TANIA, M. (2012): Nutritional and medicinal importance of Pleurotus mushrooms: An overview. Food Rev. Int., 28, 313-329.

Kim, S.K., Hong, U.P., Kim, J.S., Kim, C.H., Lee, K.W., Cho, S.E., Park, K.H. \& LeE, M.W. (2007): Antidiabetic effect of Auricularia auricula mycelia in streptozotocin-induced diabetic rats. Natural Product Sciences, 13, 390-393.

KrüzSelyi, D., KovÁcs, D. \& VetTeR, J. (2016): Chemical analysis of king oyster mushroom (Pleurotus eryngii) fruit bodies. Acta Alimentaria, 45, 20-27.

Lelley, J. \& Vetter, J. (2005): The possible role of mushrooms in maintaining good health and preventing diseases. -in: Mushroom biology and mushroom products, Proceedings of the Fifth International Conference on Mushroom Biology and Mushroom Products 8-12 April 2005, Shanghai China, pp. 412-419.

Lisiecka, J., Sobieralski, K., SiwUlski, M. \& JAsinska, A. (2013): Almond mushroom Agaricus brasiliensis (Wasser et al.) Properties and culture conditions. Acta Sci. Pol. Hortoru., 12, 27-40.

Manzi, P. \& Pizzoferrato, L. (2000): Beta-glucans in edible mushrooms. Food Chem., 68, 315-318.

Mattila, P., Könkö, K., Eurola, M., Pihlava, J.M., Astola, J. \& Vahteristo, L. (2001): Contents of vitamins, mineral elements and some phenolic compounds in cultivated mushrooms. J. Agr. Food Chem., 49, 23432348.

Pardo-Gimenez, A., Figueiredo, V.R., Dias, E.S., Pardo-Gonzalez, J.E., Alvarez-Orti, M. \& Zied, D.C. (2013): Proximate analysis of sporophores of Agaricus subrufescens Peck. ITEA Inf. Tec. Econ. Ag., 109, 290-302.

Roberfroid, M.B. (2002): Global view on functional foods: European perspectives. Brit. J. Nutr., 88, 133-138.

Royse, D.J. (2014): A global perspective on the high five: Agaricus, Pleurotus, Lentinula, Auricularia \& Flammulina. Proceedings of the $8^{\text {th }}$ International Conference on Mushroom Biology and Mushroom Products (ICMBMP8), pp. $1-6$. 
Sales-Campos, C., Araujo, L.M., Minhoni, M.T.A. \& Andrade, M.C.N. (2011): Physicochemical analysis and centesimal composition of Pleurotus ostreatus mushroom grown in residues from the Amazon. Cienc. Tecnol. Aliment., 31, 456-461.

Seto, S.W., Lam, T.Y., Tam, H.L., Au, A.L., Chan, S.W., ... \& Kwan, Y.W. (2009): Novel hypoglycemic effects of Ganoderma lucidum water-extract in obese/diabetic $(+\mathrm{db} /+\mathrm{db})$ mice. Phytomedicine, 16, 426-436.

Stajic, M., Vukojevic, J. \& Duletic-Lausevic, S. (2009): Biology of Pleurotus eryngii and role in biotechnological processes: A review. Crit. Rev. Biotechnol., 29, 55-66.

Stijve, T., Amazonas, M. \& Giller, V. (2002): Flavour and taste components of Agaricus blazei ss. Heinem - A new gourmet and medicinal mushroom. Deut. Lebensm.-Rundsch., 98, 448-453.

Sun, J., He, H. \& XIE, B.J. (2004): Novel antioxidant peptides from fermented mushroom Ganoderma lucidum. J. Agr. Food Chem., 52, 6646-6652.

Synytsya, A., Mickova, K., Jablonsky, I., Slukova, M. \& Copikova, J. (2008): Mushrooms of genus Pleurotus as a source of dietary fibres and glucans for good supplements. Czech. J. Food Sci., 26, 441-446.

Taofiq, O., Fernandes, A., Barros, L., Barreiro, M.F. \& Ferreira, I.C.F.R. (2017): UV-irradiated mushrooms as a source of vitamin $\mathrm{D}_{2}$ : A review. Trends Food Sci. Tech., 70, 82-94.

Tsai, S.Y., Huang, S.J., Lo, S.H., Wu, T.P., Lian, P.Y. \& Mau, J.L. (2009): Flavour components and antioxidant properties of several cultivated mushrooms. Food Chem., 113, 578-584.

Ulzijargal, E. \& MaU, J.L. (2011): Nutrient composition of culinary-medicinal mushroom fruiting bodies and mycelia. Int J. Med. Mushrooms, 13, 343-349.

Vetter, J. (1994): Data on arsenic and cadmium contents of some common mushrooms. Toxicon, 32, 11-15.

VetTer, J. (1996): Vanadium content of wild growing edible mushrooms. Clusiana, 35, 37-46.

Vetter, J. (2007): Chitin content of cultivated mushrooms Agaricus bisporus, Pleurotus ostreatus and Lentinula edodes. Food Chem., 102, 6-9.

Vetter, J. (2010): A gombák táplálkozási értékei (Nutritional value of mushrooms). -in: GyöRFI, J. (Ed.) Gombabiológia - Gombatermesztés (Biology of mushrooms - Mushroom cultivation). Mezőgazda Kiadó, Budapest, pp. 48-63.

Vetter, J. \& Lelley, J. (2004): Selenium level of the cultivated mushroom Agaricus bisporus. Acta Alimentaria, 33, $297-301$.

Vetter, J. \& Rimóczi, I. (1993): Crude, digestible and non-digestible proteins in fruit bodies of Pleurotus ostreatus (oyster mushroom). Z. Lebensm. Unters. For., 197, 427-428.

WANG, Y. \& XU, B. (2014): Distribution of antioxidant activities and total phenolic contents in acetone, ethanol, water and hot water extracts from 20 edible mushrooms via sequential extraction. Austin J. Nutr. Food Sci., 2, 1009-1014.

WASSER, S.P. \& WeISS, L. (1999): Medicinal properties of substances in higher Basidiomycetes mushrooms: Current perspectives (Review). Int. J. Med. Mushrooms, 1, 31-62.

Yang, B.K., Kim, D.H., Jeong, S.C., Das, S., Choi, Y.S., Shin, J.S., Lee, S.C. \& Song, C.H. (2002): Hypoglycaemic effect of a Lentinus edodes exopolymer produced from a submerged mycelia culture. Biosci. Biotech. Bioch., $66,937-942$.

Zhang, H.N., He, J.H., Yuan, L. \& Lin, Z.B. (2003): In vitro and in vivo protective effect of Ganoderma lucidum polysacharides on alloxan-induced pancreatic islets damage. Life Sci., 73, 2307-2319.

Zhang, Y., Li, S., Wang, X., Zhang, L. \& Cheung, P.C.K. (2011): Advances in lentinan: Isolation, structure, chain conformation and bioactivities. Food Hydrocolloids, 25, 196-206.

Open Acces statement. This is an open-access article distributed under the terms of the Creative Commons Attribution 4.0 International License (https://creativecommons.org/licenses/by/4.0/), which permits unrestricted use, distribution, and reproduction in any medium, provided the original author and source are credited, a link to the $\mathrm{CC} \mathrm{Li-}$ cense is provided, and changes - if any - are indicated. (SID_1) 